\title{
Do silêncio à enunciação: formação de identidades nas narrativas de Moacyr Scliar
}

\author{
Barbara Heller (UNIP) ${ }^{1}$
}

\section{Resumo}

A premissa de Tzvetan Todorov sobre a importância de o sujeito, quando fora de seu país de origem, reconhecer seu lugar de enunciação para continuar a existir, serviu como ponto de partida para analisar, em quatro narrativas de Moacyr Scliar, como cinco de seus personagens, exilados de primeira ou segunda geração no Brasil, buscaram este lugar, criando, para isso, novas identidades ou tornando-se híbridos. Edward Said, que escreveu sobre exílio; Stuart Hall, sobre identidade e, finalmente, Nestor Canclini, sobre culturas híbridas, forneceram o suporte teórico para a análise.

Palavras-chaves: Identidade; exílio; cultura.

\begin{abstract}
Tzvetan Todorov's premise on the importance of the subject, when away from his home country, to recognize the enunciation place in order to go on being, was our starting point to analyze, in four of Moacyr Scliar's narratives, the ways five of his characters, exiled in Brazil at first or second generation, searched for such a place, thus creating new identities or becoming hybrids. Edward Said, who wrote about the exile, Stuart Hall, who wrote about identity and, finally Nestor Canclini, who wrote about hybrid cultures, supplied us with theory for the analysis.
\end{abstract}

Keywords: Identity; exile; culture 
Inicio o texto com uma citação de Tzvetan Todorov, crítico literário nascido na Hungria e residente na França: "Se perco meu lugar de enunciação, não posso mais falar. Eu não falo, logo não existo”. (TODOROV, 1999: 21.).

Tal pensamento, produzido quando voltou ao seu país de origem para conferir uma palestra, depois de 18 anos de auto-exílio na França, revela a importância de o sujeito conhecer a forma e o lugar a partir do qual está enunciando. Como Todorov dominava, na ocasião, tanto a língua francesa, quanto a búlgara, questionou-se se queria ser reconhecido como búlgaro ou como francês. Se escolhesse o idioma búlgaro, equivaleria a considerar a vida que teve no outro país como um "sonho"; se escolhesse o francês, seria abrir mão da identidade que tinha com a cultura búlgara.

Já as personagens de Moacyr Scliar aqui analisadas não tiveram esta possibilidade de escolha lingüística e política. Fugindo de seus países de origem, vieram ao Brasil, sem conhecer nada de nossos costumes, nem do nosso idioma. Alguns, como será mostrado adiante, conseguiram encontrar este "lugar de enunciação" e formar uma identidade, garantindo, portanto, sua existência. Outros não tiveram a mesma sorte: oscilando entre vários lugares de enunciação, tornaram-se seres com identidades culturais diversas e terminaram a vida numa espécie de não-lugar ou não-existência.

$O$ texto que apresento a seguir mostra como as personagens extraídas de quatro romances de Moacyr Scliar - O centauro no jardim (1980); A mulher que escreveu a Bíblia (1999), O exército de um homem só (1973) e Os leopardos de Kafka (2000) esforçaram-se para conquistar um novo lugar de enunciação e uma identidade.

Guedali, protagonista de O centauro no jardim, pode ser considerado, dentre as obras analisadas, o maior expoente da crise identitária, pois oscilando entre a condição de centauro/ quadrúpede e a de humano/ bípede, não consegue definir nem a que espécie pertence, nem que tipo de corpo pretende manter vivo. Portanto, para ele, o poder de enunciação, que normalmente funciona como uma decorrência natural do ser cultural e socialmente inserido, parece um objetivo extremamente distante.

Já os outros personagens - a mulher anônima, de $A$ mulher que escreveu a Bíblia; Mayer Guinzburg, de O exército de um homem só; Benjamim e Jayme Kantarovitch, de Os leopardos de Kafka, alcançam o poder da 
enunciação, mas, como ocorreu com Todorov, nem sempre conseguem renunciar pacificamente às suas origens culturais e, apesar de optarem pela nacionalidade brasileira e pela língua portuguesa, seus discursos refletem seus lugares de enunciação - a Europa Central -, com sérias conseqüências para sua formação cultural e identitária.

Antes, porém, de debruçarmos sobre as crises de identidade por que passam os personagens aqui arrolados, é necessário partirmos de algumas premissas comuns, estabelecidas por Stuart Hall, sobre identidade cultural, por Canclini, sobre cultura híbrida, e por Edward Said, sobre exílio.

\section{Identidade cultural, culturas híbridas e exílio}

As três concepções de identidade cultural de Stuart Hall são fundamentais para a reflexão das personagens exiladas na obra de Moacyr Scliar: a) sujeito do lluminismo; b) sujeito sociológico; c) sujeito pós-moderno.

Pelo primeiro, entende-se um sujeito como "um indivíduo totalmente centrado, unificado, dotado das capacidades de razão, de consciência e de ação, cujo centro consistia num núcleo interior [...]. O centro essencial do eu era a identidade de uma pessoa" (HALL, 2003: 10).

Pelo segundo, entende-se o sujeito que deixa de ser individualista, que se forma na relação com outras "pessoas importantes para ele, que mediavam para o sujeito os valores, sentidos e símbolos - a cultura - dos mundos que ele/ela habitava. [...] A identidade é formada na interação entre o eu e a sociedade" (HALL, 2003: 11).

Pelo terceiro, entende-se o sujeito fragmentado, composto não mais de uma única, mas de várias identidades, algumas vezes contraditórias ou nãoresolvidas. "O sujeito assume identidades diferentes em diferentes momentos, identidades que não são unificadas ao redor de um 'eu' coerente. Dentro de nós há identidades contraditórias, empurrando em diferentes direções, de tal modo que nossas identificações estão sendo continuamente deslocadas" (HALL, 2003:13).

Embora Stuart Hall declare que as três concepções de sujeito são simplificações, elas são bastante eficientes para mostrar como os protagonistas 
de Scliar, nos romances O centauro no jardim, A mulher que escreveu a Bíblia, O exército de um homem só, Os leopardos de Kafka esforçam-se para entender que o sujeito centrado, único, identificado consigo mesmo e com seu grupo - a família de fortes tradições judaicas - não consegue se bastar e acaba entrando em profundos conflitos consigo mesmo, muitas vezes abandonando suas raízes culturais para, depois de um longo processo de construção de identidade/alteridade, retomá-las de forma mais pacífica e harmoniosa.

Já o conceito de cultura híbrida, proposto por Canclini, designa "as misturas interculturais propriamente modernas, entre outras, aquelas geradas pelas integrações dos Estados nacionais, os populismos políticos e as indústrias culturais" (CANCLINI, 2003: XXX).

Os personagens dos quatro romances de Scliar, como são exilados, acabam funcionando como agentes de uma mistura intercultural. Mesmo pouco adaptados ao novo contexto em que estão inseridos, acabam, de uma forma ou de outra, influenciados pelo Estado e pela indústria cultural. Apenas para citar como exemplo, cito a passagem, que será retomada mais à frente no texto, em que o pai de Mayer Guinzburg (personagem do O exército de um homem só) interpreta os conceitos de propriedade de Marx sob a ótica dos textos judaicos sagrados, diferentemente de seu filho, que os conhece por meio da circulação das obras impressas do pensador alemão.

Os personagens de Scliar são exilados de primeira ou de segunda geração e, se analisados sob a proposta de Canclini de hibridismo, ganham e perdem com a experiência da mudança definitiva de país: "[...] é atraente tratar a hibridação como um termo de tradução entre mestiçagem, sincretismo, fusão e outros vocábulos empregados para designar misturas particulares. Talvez a questão decisiva não seja estabelecer qual desses conceitos abrange mais e é mais fecundo, mas, sim, como continuar a construir princípios teóricos e procedimentos metodológicos que nos ajudem a tornar este mundo mais traduzível, ou seja, convivível em meio a suas diferenças, e a aceitar o que cada um ganha e está perdendo ao hibridar-se" (CANCLINI, 2003: XXXIX).

No entanto, a experiência do exílio não é desprovida de frustrações e sofrimento. Como lembra Edward Said (SAID, 2003: 47), o exílio é produzido 
por seres humanos para outros seres humanos que, obrigados a se afastar de suas tradições, de suas fontes de renda, de suas tradições, língua e cultura, para ficar em apenas poucos itens, se vêem obrigados a se instalar em outros lugares, muitas vezes vivendo miseravelmente, saudosos de suas origens. $O$ exilado, que sente ser um "diferente", muitas vezes se recusa a pertencer a outro lugar e se torna intransigente, passando boa parte de sua vida tentando compensar as perdas, criando um novo mundo - híbrido.

\section{Culturas híbridas}

Guedali - protagonista de O centauro no jardim

Assim começa o romance: Agora é sem galope. Agora está tudo bem. Somos, agora, iguais a todos. Já não chamamos a atenção de ninguém. [...] Esquisitos, nós? Não. Na semana passada veio procurar a Tita o feiticeiro Peri e, aquele sim, era um homem esquisito - um bugre pequeno e magro, de barbicha rala, usando anéis e colares, empunhando um cajado e falando uma língua arrevesada. Pode parecer inusitado uma criatura tão estranha ter vindo nos procurar; contudo qualquer um é livre para tocar campainhas. E, mesmo, quem estava vestido esquisito era ele, não nós. Nós? Não. Nós temos uma aparência absolutamente normal (SCLIAR, 1997: 10).

Sem qualquer referência anterior, o leitor do romance depara-se com este narrador em primeira pessoa, que confessa imenso alívio em ser, agora, "igual a todos", em não ser mais "esquisito". Estranho é o outro - o tal Peri que se veste e se enfeita de forma estranha, além de falar uma "língua arrevesada".

Já nestes dois primeiros parágrafos, portanto, nota-se a necessidade de o narrador pertencer a um grupo com o qual quer e consegue se identificar trata-se dos amigos, dos próprios filhos e dos filhos dos amigos. À medida que a leitura avança, o leitor passa a saber que o narrador, ou seja, o protagonista Guedali, nasceu numa fazenda no interior do Rio Grande do Sul, sob a forma de um centauro, e que sua infância foi permeada de terrores e de pequenos prazeres. A tormenta identitária por que passa o jovem Guedali pode ser 
reconhecida nesta passagem, na qual ele se percebe como quadrúpede e, ao mesmo tempo, como descendente de pais humanos: "[...] sou um centauro, um ser mitológico, mas sou também o Guedali Tartakovsky, o filho de Leão e Rosa, o irmão de Débora, Mina e Bernardo; o judeuzinho. Graças a isso não enlouqueço [...]" (SCLIAR, 1997: 34).

À medida que o tempo passa e Guedali cresce, suas dúvidas a respeito de sua origem inquietam-no cada vez mais. Já morando em Porto Alegre, escondido no galpão reformado nos fundos da casa, começa sua incansável maratona de leituras para encontrar respostas às suas origens: parte da literatura contemporânea ao Velho Testamento e à mitologia grega. Dá prosseguimento com Marx, Freud e Scholem Aleichem, todos de origem judaica - e também não acha explicações para sua origem.

Apenas quando Guedali, já adulto e casado com a centaura Tita, resolve sofrer uma cirurgia na distante Marrocos para abandonar sua condição de quadrúpede, é que suas crises de identidade se acalmam, mas por pouco tempo. Nova crise se instala: Guedali não consegue conviver com seu corpo totalmente humano e, 13 anos mais tarde, volta ao Marrocos para pedir ao mesmo cirurgião que o transforme em centauro novamente. É quando conhece Lolah, uma esfinge, isto é, um ser mitológico, metade mulher, metade leoa. Diferentemente do protagonista, ela não pode ser transformar-se em totalmente humana e, por isso mesmo, tenta convencê-lo a se tornar nem centauro, nem humano, mas um homem-leão.

É interessante observar que a crise de identidade de Guedali tampouco se resolve neste momento do romance, quando lhe é oferecida uma terceira opção, jamais pensada por ele até então. Sua escolha, portanto, deveria recair entre o corpo original (centauro) e o corpo social (humano). Se atendesse ao primeiro, deixaria de ser um igual no seu meio familiar e social; se optasse pelo segundo, corria o risco de sempre sentir uma falta, uma ausência, pois, sob a forma humana, Guedali tornava-se um sujeito cujos instintos deveriam ser ainda mais reprimidos e controlados. Como a cirurgia não chega a ser realizada, Guedali continua, por força do acaso, na sua condição de humano até o final da história, embora sentisse nas veias o pulsar de um centauro. 
Podemos afirmar que Guedali, apesar de exímio leitor dos mais diversos gêneros de texto, não é capaz de eleger um único lugar de enunciação, pois oscila entre a condição humana e a de centauro. Mesmo assumindo um corpo definido, é um sujeito híbrido e, assim como Todorov, não sabe que língua falar, isto é, se a dos humanos ou a dos centauros.

A mulher feia - protagonista de A mulher que escreveu a Bíblia

Sem nome próprio, a protagonista deste romance tem como principal característica sua enorme feiúra facial, embora fosse "boa de corpo". Descobre, por meio de terapia de vidas passadas, ter sido uma antiga cidadã dos tempos bíblicos em Canaã e filha de um pastor de cabras.

Buscar nas reminiscências inconscientes de seu passado a explicação do insucesso na vida afetiva permitiu à protagonista conquistar um final feliz: desiste das últimas sessões de análise, escreve sua biografia sob anonimato e sai abraçada com seu amor reconquistado para um novo e desconhecido destino.

A cena em que se percebe, numa sessão terapêutica de regressão, como muita feia, é a que Ihe traz a marca identitária: "Eu tinha me olhado no espelho e pronto: o que tinha visto, não esqueceria. Mas eu precisava, senão de consolo, ao menos de explicação. Tinha de saber a razão pela qual coubera a mim tamanho quinhão de feiúra. A Natureza não poderia ter procedido em vão, ao obrar a minha face" (SCLIAR, 1999: 25-26).

Assim como Guedali, de O centauro no jardim, a protagonista tenta achar explicações para sua aberração. Embora não se tratasse de uma mulher que beirava a falta de limite entre o humano e o animal, como no caso de Guedali, a protagonista sente-se um ser tão à parte do resto da humanidade, que busca na origem familiar (e não na leitura de textos diversos) a explicação de seus defeitos faciais. Conclui que sua feiúra devia-se ao fato de sua mãe, durante a gravidez, ter admirado tanto a montanha em frente da aldeia, que ocorreu um processo simbiótico entre o feto que se formava - ela mesma - e a visão da sua mãe: Uma protusa rocha era o meu nariz; a escura entrada de uma das muitas cavernas correspondia à minha boca. Muitos vêem faces em 
nuvens; eu via na montanha - monumento ao insólito - a reprodução de meu próprio rosto. As impressões que minha mãe tivera durante a gestação se haviam gravado de maneira indelével na face da filha (SCLIAR, 1999: 27).

Depois de casada com o rei Salomão, a protagonista recebe de seu marido a missão de auxiliar os sábios anciãos a escrever a Bíblia, tarefa que também a ajuda a assumir sua identidade e a se valorizar: "Naquela noite, olhei-me num espelho. Mais uma vez, achei que havia mudado: minhas feições agora eram um pouco menos duras, a expressão um pouco mais doce. Eu tinha a certeza de que estava a caminho - na vida e no texto" (SCLIAR, 1999: 143).

Diferentemente de Guedali, que cirurgicamente rejeita sua identidade de centauro, a protagonista de $A$ mulher que escreveu a Bíblia pacifica-se quando entende sua feiúra, chegando até a reconciliar-se com ela, sentindo-se um pouco mais bela ao perceber que consegue tornar-se sedutora pelo poder que tem com as palavras escritas.

Trata-se, talvez, de uma Scherazade ao contrário e mais refinada: enquanto esta é linda e adia sua própria condenação à morte pela capacidade de narrar histórias ao sultão, a protagonista de A mulher que escreveu a Bíblia salva-se porque consegue atingir plenamente o lugar da enunciação. Ela não só é a autora de uma versão da Bíblia em uma vida pregressa, como escreve sua autobiografia.

No final do romance, a protagonista sente-se feliz e pronta para assumir novos destinos.

Mayer Guinzburg - protagonista de O exército de um homem só

Neste romance, o protagonista tem dupla identidade: Mayer Guinzburg nome e sobrenome marcadamente de origem judaica - e Capitão Birobidjan patente militar no lugar do primeiro nome e sobrenome também marcadamente estrangeiro $^{2}$. Trata-se de um personagem que ora se comporta ora como militar, ora como civil.

Tal construção ambígua no que se refere à construção da identidade do protagonista não parece mero acaso. $O$ romance foi escrito e publicado na 
década de 70 - auge da ditadura militar no Brasil - e Mayer Guinzburg era não só um exilado russo, como também um comunista convicto. Um sujeito, portanto, que reunia duas características que o tornariam imediatamente suspeito de subversão, caso caísse nas mãos da polícia política brasileira da época.

Seu exílio começa em 1916, quando parte da Rússia aos 9 anos, na companhia de seus pais e irmão. Instalado em Porto Alegre, mais especificamente no Bairro Bom Fim, o protagonista integra-se facilmente ao meio social.

$\mathrm{Na}$ medida em que cresce e acompanha por meio de leituras as mudanças políticas por que passa seu país de origem, Mayer Guinzburg sonha com uma nova sociedade no Brasil, em que todos pudessem ser tratados como "companheiros", dividindo tarefas e responsabilidades, sob sua liderança inquestionável. Para executar essa empreitada, portanto, ser apenas Mayer Guinzburg não bastava. Era necessário agregar à sua pessoa um nome que Ihe conferisse respeito e autoridade e, ao mesmo tempo, que intimidasse possíveis inimigos - reais ou fictícios. "Capitão Birobidjan" encaixava-se perfeitamente a tais exigências, uma vez que reunia simultaneamente uma alusão a uma patente militar (o que, por si só, numa sociedade civil, o distinguiria dos demais) e homenagearia o local previsto em seu país natal para os judeus viverem em segurança.

Assim, torna-se possível ao personagem manter tanto suas convicções políticas, quando responde por Capitão Birobidjan, quanto ser visto como parte integrante dos exilados judeus, quando responde por Mayer Guinzburg. Aparentemente, o personagem, conforme sua conveniência, ora assumia o nome Mayer, ora Capitão Birobidjan.

Quando Mayer, aos 22 anos, travestido de Capitão Birobidjan, dá início, pela primeira vez, à instalação de "sua" Birobidjan, isto é, da Nova Birobidjan, em 1929, com seus amigos da comunidade judaica, num sítio abandonado, comporta-se tão autoritariamente, que a experiência termina em poucos dias.

No segundo retorno a Nova Birobidjan, em 1942, o insucesso se repete, mas, desta vez, parte sozinho e, depois de sofrer vários ataques de desocupados que por ali ficavam, recebe Santinha, uma jovem brasileira de 
feições grosseiras. Nesta ocasião, o protagonista já é um homem maduro, com seus 35 anos, pai de dois filhos.

Sua primeira atitude relativa a Santinha é mudar seu nome, considerado reacionário por Mayer, para Rosa de Luxemburgo. Embora não entendesse muito bem os motivos alegados pelo protagonista, a carência material de Santinha é tão intensa, que ela rapidamente aceita sua nova identidade. Nesta sociedade que então começa a se formar habitam dois indivíduos que, por motivos diversos, substituem seus nomes de origem. Se para Santinha ser chamada de nome diferente é mero detalhe, para o protagonista renomear a si mesmo e aos outros estava carregado de conteúdo simbólico, pois ele entendia que, agindo assim, as pessoas adquiriam nova identidade, rompendo com a anterior.

Poucos dias depois, a Rosa de Luxembugo brasileira presta todos os tipos de serviços ao seu "companheiro", como Mayer pede para ser chamado: faz biscates, pede esmolas, limpa a casa, planta milho, improvisa a cama onde dormem juntos.

Nos dois anos em que o protagonista tenta implantar a Nova Birobidjan, passa fome e veste-se com farrapos. Quando é abandonado por Rosa, que reassume o nome de Santinha, resiste mais alguns dias, mas acaba retornando à vida familiar por mais dez anos.

Finalmente, em 1952, Mayer, juntamente com um amigo da comunidade judaica, torna-se empresário no ramo imobiliário. No entanto, embora o projeto fosse promissor, inicia-se a decadência irreversível do protagonista. Em 1957 ele já perdeu a empresa, o casamento, a convivência com os filhos, a amizade dos antigos companheiros judeus. Mayer acaba sustentado por um de seus filhos e é por ele instalado numa pensão onde, pela terceira vez, vislumbra Nova Birobidjan.

Neste momento do romance há passagens bastante significativas no que se refere à fragmentação identitária de Mayer. Instalado na pensão, passa a conviver, entre outros, com David Benveniste, um judeu egípcio de 81 anos.

Disputando com ele pelo único banheiro da pensão e sempre esperando pela próxima refeição, Mayer passa de um estado inicial de irritação para o de delírio nos dois anos em que lá morou. Sua convivência com David, com quem 
supostamente teria maior identidade, uma vez que ambos são velhos e judeus orientais, potencializa a ruptura do frágil equilíbrio emocional de Mayer.

O trecho a seguir é significativo do que estou pretendendo mostrar:

É 7 de junho [de 1967], o terceiro dia da Guerra dos Seis Dias. Os blindados israelenses avançam pelo Sinai. Mayer Guinzburg e Benveniste ouvem com atenção. Terminado o informativo, Benveniste apaga o rádio.

- É - murmura - parece que a coisa está decidida.

- Parece - diz Mayer, cautelosamente. Sente que vai começar uma discussão.

- Bem feito para o Nasser - Benveniste está irritado. - É por causa dele que estou aqui nesta pensão. Podia estar no meu escritório, no Cairo... Bem feito. Aquele demagogo. Pagou caro.

- No entanto - pondera Mayer - é um homem de grande personalidade. Um verdadeiro líder; Ben Gurion mesmo admite isso. Tentou tirar o seu país do subdesenvolvimento...

- Isto é verdade - reconhece David. (SCLIAR, 1983, pp. 145-6).

Neste excerto pode-se identificar não só uma tensão crescente no ar entre Mayer e David, "[Mayer] sente que vai começar uma discussão", como a explicação de um outro exilado, proveniente de outro país, dos motivos que o trouxeram ao Brasil: a demagogia de Nasser, então presidente do Egito.

Embora fosse esperado de Mayer que desse apoio ao seu colega pensionista na crítica a Nasser, uma vez que políticos árabes costumam representar ameaça à sobrevivência física dos judeus e à permanência do Estado de Israel, Mayer faz o contrário e, citando Ben Gurion, um dos líderes da Independência de Israel, enaltece o lado empreendedor de Nasser.

Mayer, embora tivesse em comum com David a exigência do exílio e a religião, faz questão de marcar sua diferença com seu interlocutor. É como se a disputa inicial pelo tempo de permanência no banheiro entre eles ganhasse novas dimensões, isto é, o conflito migra do universo privado (representado, genial e metaforicamente, pelo banheiro), para o público, para o de pátria.

Como ambos têm origem nacional diversa - a Rússia para Mayer e o Egito para David - em nenhum momento o protagonista percebe em David um aliado, mas sempre um oponente, a quem valia a pena provocar, toda vez que 
pudesse, como sugere a continuação do diálogo anterior entre os dois personagens:

- Mais cedo ou mais tarde - interrompe Mayer - vocês teriam de enfrentá-lo [a Nasser]. Afinal de contas era um ditador. Um tipo destes sempre muda de uma hora para outra.

- Pode ser - diz David Benveniste. - Mas o certo é que nós vivemos bem no Egito. Há séculos. [...] Mas vocês, judeus russos, tinham de inventar o sionismo e Israel. Porque estavam incomodando vocês com anti-semitismo e pogroms, acharam que deviam nos comprometer. Nós não tínhamos nada a ver com a situação de vocês. Estávamos prosperando...

- Claro - exclama Mayer, irritado. - Enquanto o povo egípcio vivia na maior miséria vocês nadavam em dinheiro!

- É verdade - reconhece Benveniste. - No fundo, éramos estrangeiros. E suportar a inveja daquela gente não era fácil. Mais cedo ou mais tarde teríamos de sair de lá e ir para outro país, para Israel, quem sabe...

- Bem - Mayer agora está conciliador -, no fundo, eles não tinham o direito de expulsar vocês.[...] (SCLIAR, 1983: 146).

A transcrição acima é bastante sugestiva, pois não só modula o humor de Mayer entre a provocação e a conciliação, como faz com que David expresse com muita clareza sentimentos possivelmente vividos também por Mayer: sentir-se sempre estrangeiro, seja no país de origem, seja no país onde vive o exílio. Referir-se aos outros compatriotas egípcios como "aquela gente", como faz David, mostra que, apesar da nacionalidade comum, é a religião judaica que o faz sentir-se diferente dos demais. Pode-se afirmar o mesmo em relação a Mayer que, como bem lembra David, apenas por ser judeu, é vítima dos pogroms na Rússia.

Ou, em outras palavras: tanto David, como Mayer, vivem o exílio nos países em que nasceram. No Brasil, portanto, vivem o exílio dentro do exílio. Nem mesmo a religião e o desolamento em comum são capazes de torná-los aliados.

A desarticulação de Mayer é quase tão antiga quanto sua própria vida. Desapegado de seus pais e irmãos, quer viver num mundo à parte, a "Nova Birobidjan", que não consegue pôr em prática, mas que torna pública sua confusão emocional e política. Tampouco a religião judaica o auxilia na 
constituição de uma identidade mais fixa. Recusa sistematicamente a leitura dos livros sagrados sugeridos pelo pai e propõe, no seu lugar, os textos de Marx, cujas idéias assim são explicadas ao velho Guinzburg: "[Marx] sabe tudo! Sabe que não deve haver fome, nem injustiça. Não deve haver "meu", nem "teu"; deve ser: "O que é meu é teu; o que é teu é meu". (SCLIAR, 1983: 25).

Como se pudesse prever o futuro sombrio do filho, o velho pai assim the responde: "Na Mishná ${ }^{3}$ está escrito que há quatro tipos de homens: o vulgar diz: "O que é meu é meu; o que é teu é teu"; o perverso diz: "o que é meu é meu; e o que é teu também meu". Quanto a mim, prefiro as palavras do homem santo, que diz: "O que é meu é teu; e o que é teu é teu". Mas tu, meu filho, dizes: "O que é meu é teu; e o que é teu é meu". E isto, segundo a Mishná, são as palavras do excêntrico, do estranho entre os homens. Acho que vais sofrer muito, filho" (SCLIAR, 1983, p.25).

Desprovido, portanto, de três tipos de identidades - a do nome próprio, a nacional e a religiosa -, e excluído da convivência familiar, a fragmentação de Mayer é inevitável. No final da história, não fica muito claro se o protagonista surta seriamente ou se está morrendo. O que fica explícito é que Mayer não conseguiu, nem ao longo de toda sua vida, nem nos derradeiros momentos (na hipótese de ele estar sofrendo um enfarte nas cenas finais) construir uma referência fixa sobre si mesmo. Assim como Guedali, Mayer não consegue alcançar um lugar de enunciação e seus discursos soam como alucinações.

Benjamin e Jayme Kantarovich - personagens de Os leopardos de Kafka

Neste romance de Scliar, publicado em 2000, é Benjamin Kantarovich quem vem ao Brasil em 1917, também com seus pais e irmão, exilados da Bessarábia.

Assim como Mayer, Benjamin é comunista e sua vida familiar e política é igualmente desastrosa. Ainda no seu país de origem, Benjamin, que ganhara de seu primo um exemplar em iídiche do Manifesto Comunista, compartilha com ele o mesmo sonho: "Um mundo em que ninguém seria perseguido, em que os judeus seriam iguais a todas as pessoas" (SCLIAR, 2000: 15). 
Embora em Um exército de um homem só a explicação do que é comunismo seja mais bem-humorada que a descrita acima, ambos romances profetizam sociedades onde não haveria mais perseguidos e, portanto, exilados ("os judeus seriam iguais a todas as pessoas"), caso adotassem o comunismo como sistema político e econômico.

A morte repentina e precoce do primo, de quem herda uma missão secreta, é a deflagradora da mudança de vida de Benjamin. Deve sair da aldeia, ir de trem a Praga, hospedar-se num determinado hotel, procurar um homem de quem nunca ouvira falar (mas sabia ser escritor e judeu), cujo nome e telefone constavam dentro de um envelope fechado e escondido dentro do $O$ manifesto comunista e lhe dizer a seguinte senha: "Estou encarregado de receber o texto".

Tal homem iria entregar-Ihe uma mensagem secreta, que só seria decifrada se sobreposta à folha que havia no envelope. Apenas depois de concluída esta parte da tarefa, é que Benjamin saberia o alvo de sua missão e o que deveria fazer.

Para quem nunca saiu da aldeia natal, só a viagem a Praga já era uma aventura e tanto... Pode-se dizer que nesta ocasião Benjamin experimentará, pela primeira vez, mas não a única, a sensação de um exilado: estranhamento do local, falta de domínio da língua local, ausência de referências familiares. Embora Benjamin estivesse a curta distância de seu local de origem, Praga não the será mais familiar que Porto Alegre, cidade que o receberá aproximadamente um ano mais tarde, como veremos mais adiante no texto.

Benjamim parte da Bessarábia e, como planejado, consegue desembarcar em Praga, mas percebe, assim que se instala no hotel, ter esquecido no vagão o bornal em que estavam o Manifesto Comunista e o envelope.

Evidentemente, todos os esforços para recuperar o bornal são inúteis. Nos dias subseqüentes, já conformado com seu esquecimento, tenta descobrir quem seria 0 tal homem que deveria completar sua mensagem cifrada. Caminha a esmo pela cidade e, embora o narrador sugira ser mero acaso, Benjamin "'quando deu por si" estava num lugar que the pareceu familiar: em alguns lugares havia até letreiros em hebraico. Era a rua Maisel, no antigo 
gueto de Praga. Diante dele, a lendária Alteneuschule, a velha sinagoga, maciça e sombria" (SCLIAR, 2000: 36).

Não parece ser mera coincidência que as soluções de seu problema comecem a surgir justamente no bairro judeu, isto é, no único local da cidade estranha que lhe é menos estranho. Por intermédio do zelador da velha sinagoga, Benjamin fica sabendo que não muito longe dali morava um escritor judeu, Franz Kafka. Convicto de que era o homem com quem deveria entrar em contato, descobre seu número de telefone, faz a ligação e, emocionado, repete-Ihe a senha aprendida com seu primo.

Kafka, por sua vez, não parece surpreso com o telefonema e entrega, no dia seguinte, um texto em alemão para Benjamin. Mesmo depois de tê-lo traduzido para o iídiche, com a ajuda do zelador da sinagoga, Benjamin não consegue entendê-lo e visita Kafka, na esperança de que este pudesse decifrálo. Apesar de gentilmente recebido pelo autor, este nada lhe acrescenta.

Vencido pelo cansaço, pela falta de agasalhos adequados e pelo dinheiro que ameaçava acabar, Benjamin decide pelo fim de seu primeiro exílio e volta à sua aldeia. De concreto, tudo que sobra de sua aventura em Praga são o papel com o texto de Kafka, que jamais afasta de si, e a sensação de fracasso.

Logo que retorna, sente-se completamente adaptado ao meio, e aprende com seu pai, sem dificuldades, o ofício de alfaiate. Em 1917, temendo os bolcheviques, Benjamin embarca para o Brasil com sua família.

Assim como Mayer, a família Kantarovich instala-se no Bairro Bom Fim, em Porto Alegre. Benjamin trabalha como alfaiate, mas afasta-se da família, e assim como Mayer Guinzburg, e pelos mesmos motivos - a adesão ao pensamento comunista - é considerado pelos parentes mais próximos um "esquisitão".

Enquanto isso, o irmão de Benjamin casa-se, separa-se, mas antes tem um filho - Jaime - o único parente por quem sente afeto. Portador de seqüelas de paralisia infantil, Jaime, ao saber que seu tio, apesar de morar modestamente, era proprietário de uma selecionada biblioteca particular, passa a freqüentar sua casa. 
Militante do movimento estudantil desde a adolescência, Jaime, que se tornara stalinista, tem discussões acaloradas com seu tio trotskista, mas nem essa diferença de opiniões diminui o afeto que sentem um pelo outro.

Jaime pouco convive com seus pais ou com o restante da família, assim como Mayer e o próprio Benjamin. Diferentemente de seus colegas de partido, Jaime aprecia os textos de Kafka, que aprende a ler no original. Ou seja: mesmo sendo brasileiro, Jaime também sente na pele a experiência do exilado, seja no âmbito familiar, seja na militância política. Para Jaime, o exílio certamente é uma sensação mais ambígua do que para seu tio e para Mayer Guinzburg, uma vez que ele não é expulso de seu país natal, domina a língua nacional, torna-se militante de um partido político e namora uma brasileira. Mas, certamente, ele é um outro, uma vez que, exceto pelo seu tio, deixa de conviver com sua família de origem, é portador de deficiência física e apreciador de um autor desprezado pelos colegas de partido.

Em 1964, quando estoura o golpe militar no Brasil, Jaime está cursando o primeiro ano de faculdade e protesta publicamente contra o governo. Perseguido pela repressão, é aconselhado pelos partidários a mudar-se para São Paulo. A falta de dinheiro para a nova vida é resolvida por Benjamin que não só lhe conta pela primeira vez sua aventura em Praga, como the oferece o papel com o texto e assinatura de Kafka que, segundo avaliadores, deveria valer pelo menos oito mil dólares.

Jaime, no entanto, acaba preso por agentes do Deops ainda em Porto Alegre. Mais uma vez, é o tio quem o socorre. Suborna o delegado, com o melhor terno que havia feito em toda sua vida, para libertar o sobrinho.

O que o tio não sabe até chegar à delegacia é que o texto de Kafka, que sai do seu cofre e entra nos bolsos de Jaime, vai parar nas mãos do delegado. No lugar de ser a solução para Jaime, aquela produção literária de Kafka inicialmente complica a tensa negociação de libertação, mas como as palavras do autor tcheco também não fazem sentido algum ao delegado que, até aquele dia, nunca ouvira sequer falar em Kafka, o pior acontece: só "por precaução", o delegado, com o novo terno devidamente aceito, pica e joga fora o texto kafkiano.

Jaime é libertado e, mesmo sem dinheiro e sem o texto de Kafka, embarca para São Paulo. Na mesma noite, o tio, com a ajuda de um motorista 
de táxi, consegue roubar da delegacia uma lata de lixo e assim recupera um único pedaço do original kafkiano: um fragmento da primeira frase, de um total de quatro.

Na noite que precede sua morte, em 1980, Benjamin delira e pronuncia algumas palavras do texto kafkiano. Seu sobrinho que o acompanha no leito de morte sabe que Benjamin está, finalmente, decifrando a misteriosa mensagem e conquistando seu lugar de enunciação. Já para Jayme, o lugar de enunciação é o movimento estudantil, pelo qual assume os mais variados riscos e do qual se torna militante. É por meio dele que Jayme consegue, também, encontrar seus pares - além de seu tio, único parente.

\section{Considerações finais}

Como pudemos ver nas análises identitárias de Guedali, de $O$ centauro no jardim e da protagonista de $A$ mulher que escreveu a Bíblia, ambos os personagens lutam para saber, afinal, a qual grupo social pertencem e que lugar ocupam na sociedade em que se encontram. Ambos sabem que têm ascendência judaica: Guedali conhece pormenorizadamente as histórias das perseguições religiosas de seus pais na Rússia e as condições que enfrentaram para se instalar no Rio Grande do Sul. Já a protagonista de $A$ mulher que escreveu a Bíblia aprende por meio de terapia de vidas passadas que muitos séculos antes viveu na Palestina e habitou o palácio do rei Salomão, com suas outras mulheres e concubinas. No entanto, desconhece referências sobre as gerações intermediárias, sobre as formas pelas quais sobreviveu e veio viver no Brasil, num continente tão distante da bíblica Palestina.

Já os demais personagens, - Mayer Guinzburg, Benjamin e Jayme Kantarovich - conhecem bastante bem suas origens, porque são os próprios exilados ou seus primeiros descendentes.

À primeira vista, nenhum dos personagens analisados questiona sua brasilidade: parece que, em alguma medida, todos se reconhecem como sendo brasileiros, mesmo os não nascidos aqui. No entanto, se lembrarmos a premissa de Todorov do início do texto, veremos que das cinco personagens 
analisadas dos quatro romances, apenas a protagonista de $A$ mulher que escreveu a Bíblia e Jayme Kantarovich alcançam, de fato, um lugar de enunciação, confirmando não só sua "existência", como escreve Todorov, mas sua identificação cultural com o Brasil.

Guedal e sua esposa Tita, Mayer Guinzburg e Benjamin Kantarovich, ainda na acepção de Todorov, parecem personagens mais flutuantes no que diz respeito à criação de uma identidade cultural, uma vez que não têm clareza dos seus lugares de enunciação. Guedali oscila entre se reconhecer como quadrúpede ou bípede; Mayer Guinzburg fragmenta tanto sua identidade, como sugerem os dois nomes pelos quais atende, que não sabe nem que sujeito ele mesmo é, de qual lugar está falando e para quem. Já Benjamin Kantarovich não consegue desapegar-se de seu passado distante e da tentativa de estabelecer vínculos com o movimento trotskista da Europa Central. Ele sai Bessarábia, mas parece nunca ter chegado ao Brasil, embora tenha passado a maior parte de sua vida neste país.

A única personagem que, de fato, parece assumir completamente um lugar de enunciação, é, talvez não por acaso, a única personagem feminina: a protagonista de $A$ mulher que escreveu a Bíblia. Exímia na escrita, transcreve na sua versão para a Bíblia episódios que testemunha e pesquisa e, muitos séculos depois, é autora de uma autobiografia.

Entender por que Scliar privilegiou uma personagem feminina no que se refere à conquista de um lugar de enunciação é motivo de outro texto e de pesquisa. No entanto, o que fica evidente é que o autor, também filho de exilados, por meio destas cinco personagens dos quatro romances analisados, representou uma cultura marcada pelo hibridismo e confirmou a premissa de Todorov, isto é, a necessidade de se buscar um lugar de enunciação para podermos existir. 
Referências bibliográficas

CANCLINI, Nestor García. Culturas híbridas. São Paulo: Edusp, 2003.

HALL, Stuart. A identidade cultural na pós-modernidade. Rio de Janeiro: DP\&A, 2003.

SAID, Edward. Reflexões sobre o exílio. São Paulo: Companhia das Letras, 2003.

SCLIAR, Moacyr. A mulher que escreveu a Bíblia. São Paulo: Companhia das Letras, 1999.

. O centauro no jardim. Porto Alegre: L\&PM, 1997.

. O exército de um homem só. Porto Alegre: L\&PM, 1983.

. Os leopardos de Kafka.São Paulo: Companhia das Letras, 2000.

TODOROV, Tzvetan. O homem desenraizado. Rio de Janeiro: Record, 1999.

\footnotetext{
${ }^{1}$ Doutora em Teoria Literária (IEL/Unicamp) e mestre em Comunicação (ECA/USP). Docente do Mestrado em Comunicação da Universidade Paulista (Unip) e do Centro Universitário Fundação Santo André, na graduação em Letras.

2 "Birobidjan" é o nome de uma área localizada na Sibéria Oriental que, em 1928, foi destinada pelo governo soviético aos judeus para que ali estabelecessem uma região judaica autônoma e assim barrassem a expansão japonesa.

${ }^{3}$ Enquanto a Torá é considerada a compilação da lei oral, transmitida por Deus a Moisés no Monte Sinai, o Talmud discute e esclarece todas as leis e rituais judaicos.A Mishná, um dos dois livros do Talmud, compõe-se de uma série de declarações, organizadas por assunto e tópico, que ensinam as leis, a tradição e a história judaica. Site consultado: http://www.morasha.com.br/conteudo/artigos/artigos_view.asp?a=413\&p=0, em 27/04/06.
} 